\title{
GALDÓS' USE OF YELLOW IN CHARACTER DELINEATION
}

\author{
By Vernon A. Chamberlin
}

$\mathrm{T}$ HE USE of color by Galdós has so far failed to attract the detailed attention of literary scholars. This lack of attention may perhaps be explained by the fact that Galdós is so well known and so esteemed for his external and psychological realism that scholars have not been inclined to seek special connotative values, nuances, and interest for particular colors in his literary creativity. Galdós' penchant for drawing black-and-white sketches and two recent, very careful, and highly regarded studies-which only mention in passing specific instances of Galdós' lack of concentration regarding color ${ }^{1}$-likewise fail to hint at its importance in his novels. That Galdós was interested in color, however, may be seen in his perennial use of yellow-an especially important chroma which occurs not only prominently at critical junctures in certain novels ${ }^{2}$ but also as the surname of an important character: Juan Amarillo in Gloria. ${ }^{3}$

It has become a generally accepted fact in Galdosian criticism that the names Galdós gave to his personajes were not incidental tags but were often carefully chosen to reflect essential facets of the character's personality and frequently to carry additional symbolic connotations. ${ }^{4}$ Thus when Galdós says of Juan Amarillo: "[su] apellido es de los que más admirablemente se conforman con la persona" (Iv, 584), one may reasonably surmise that Galdós had a definite use for yellow in his characterization technique.

However, yellow-complexioned personajes appear throughout Galdós' social novels from $L a$ Fontana de Oro (1870) to Casandra (1905), and one must be careful to remember that Galdós was a consummate realist as well as a symbolist. Consequently, special connotative insinuations are not apparent in the case of those characters whose jaundiced complexion is but a symptom of ill health. Galdós was well aware that any illness damaging normal liver function results in a yellowish coloring to the skin. Thus Pepe Carrillo (Lo prohibido), suffering from some "cosa de hígado" (Iv, 1738), has a "rostro demacrado, con amarillez azafranosa" (IV, 1755); and the titular protagonist Angel Guerra turns yellow after his liver has been pierced by an assassin's knife ( $\mathrm{v}$, 1532). Jaundice heralds the approaching death of the tubercular Alejandro Miquis ( $E l$ doctor Centeno; IV, 1402, 1436). ${ }^{5}$ Long years of civil service in Cuba and the Philippines-lands rampant with yellow fever and malaria-have left the cesante, Ramón Villamil (Fortunata y Jacinta, Miau), with his "piel como la cáscara de un limón podrido" ( $\mathrm{v}, 304)$ and his face as yellow as that of a "tigre viejo y tísico $(v, 554) .{ }^{6}$ Similarly Galdós says of the indiano, Agustín Caballero (La de Bringas, Tormento), "el color de su rostro [tez amarillenta (IV, 1533)] era malísimo, color de América, ... . la insignia o marca del apostolado colonizador ...." (Iv, 1467).

Furthermore, an occasional character turns momentarily-not white as a sheet, as in English-but "más amarillo que la cera"; ${ }^{7}$ and there are a number of other characters whose yellowness is not so much, or exclusively, evidence of external realism. These personajes reflect a much more subjective and symbolical character delineation than that ordinarily credited to Galdós.

One can best get at the heart of this matter through a consideration of Juan Amarillo, Galdós' most strikingly yellow character. Unlike many other characters, Amarillo is a non-reappearing personaje; he was created especially for the novel Gloria (1876-77) and appears in no other. This is the only Galdosian novel to have a Jewish hero (Daniel Morton), and Juan Amarillo is clearly cast as the opposing villain. Galdós completely and purposefully reverses a number of age-old popular concepts and

1 Walter T. Pattison, Benito Pérez Galdós and the Creative Process (Minneapolis, Minn., 1954), p. 99, n. 335; and William H. Shoemaker, "Galdós' Literary Creativity: D. José Ido del Sagrario," HR, xIX (1951), 212.

${ }^{2}$ La Fontana de Oro, Doña Perfecta, Torquemada en la hoguera, and others as will be shown in the text of this study.

${ }^{3}$ This is the only instance where Galdos ever used a color for the surname of an important character. Cf. "Ensayo de un censo de personajes galdosianos," Obras completas, ed. F. C. Sainz de Robles (Madrid), vi, 1705-2078. All references to Galdos' works in the present study are to be found in this series; volume IV is the tercera edicion (1954), and $\mathrm{v}$ and $\mathrm{VI}$ are the segunda $(1950,1951)$.

4 Shoemaker, p. 232.

5 Galdos definitely associated yellow with consumption. Fifteen years earlier, in $L a$ Fontana de Oro, he had described a lone flower in a patio as "pobre clavel amarillento y tísico" (Iv, 37). For Jacinta in Fortunata y Jacinta, yellow "tiene cierto aire de poesía mezclado con la tisis, como en $L a$ Traviata" $(\mathrm{v}, 99)$.

-Textual chronology seems to indicate that Galdós worked from the color yellow (Fortunata y Jacinta, v, 304) to the image of a tiger (Miau, v, 554, col. 2) to give Villamil a somewhat feline countenance to blend with that of the female members ("las tres Miau") of his family (p. 554, col. 1).

7 For example, el Marqués de Tellería in La familia de León Roch (rv, 856). See José M. Sbarbi, Diccionario de refranes de la lengua española (Buenos Aires, 1943), p. 64. 
makes his Jewish hero kind, noble, and generous. In contrast, the Christian villain, Juan Amarillo (his surname being the color perennially assigned to Jews by their enemies), ${ }^{8}$ is a mean, sordid, and pathologically greedy moneylender; he is also yellow-complexioned (IV, 584) and such an absolute villain that in both volumes of the novel his despicable and treacherous actions bring about the tragic denouement (IV, 584-585; 664-668).

Galdós reinforces his symbolism with a wife for the villain, who is just as greedy and equally yellow. She has "amarillas manos," "dorada piel de la frente" (IV, 598); and her little grey eyes become "a veces dorados" (IV, 596). When la de Amarillo, whose countenance has a "brillo metálico," gets an opportunity to meet Ester Morton, a Jewess whom she knows to be wealthy, "la cara de Teresita brillaba más entonces. Aquel lustre metálico era el síntoma de las agitaciones de su alma ...." (IV, 652). Here Galdós is expressing a sentiment similar to that of Abraham Cowley, the seventeenth-century English writer, who described avariciousness as "the love of gold-that jaundice of the soul which makes it look so gilded and so foul." Galdós' technique, not only here but in many of his other social novels, is to reflect the jaundice-gilded, foul inner condition of the personaje by using yellow in the external physical description of the character.

An examination of the novels preceding Gloria reveals that Galdós' use of yellow to delineate greedy, obnoxious, and villainous characters did not originate in his desire to remove the traditionally stigmatizing color from his Jewish hero and stamp it aggressively (by means of surname and yellow complexion) upon the latter's villainous antagonists. On the contrary, Galdós, from the beginning of his career, held yellow to be an important and useful color for delineating antipathetic characters. In his first novel, La Fontana de Oro (1870), "Coletilla" (D. Elías Morejón y Paredes) has "la piel de la frente ... amarilla y arrugada como las hojas de un incunable" (IV, 21). This personaje is not only the prime villain vis-à-vis the protagonists but also a despicable agent provocateur of the dictatorial tyrant, Fernando VII.

In the same novel, Galdós shows greater attention and, more importantly, greater artistic consistency in portraying Doña Salomé Porreño, a precursor of Gloria's Teresa Amarillo in that her yellow complexion turns out to be the main symbolic indication of her true but suppressed and undisclosed character-i.e., her avaricious lust for gold. In the novel's climactic scene (IV, 183184), when it is revealed that her niece has a secret hoard of ancient gold coins, Doña Salomé changes from the complete beata that Galdós has described throughout the story into a greedy panther-"estaba amarilla y jadeante de rencor, envidia y ansiedad." When the coins spill on the floor, she viciously attacks the others present like a wild beast, gets the money away from them in a mad scramble, and then disappears forever with the "áureas piezas."

In Galdós' second novel El audaz (1871), the man hired to kill the heroine, Clara Chacónwho is being detained as a helpless prisoner-is "flaco, amarillo y escuálido" (IV, 362). He is not only lascivious but so cowardly that he bungles the murder (IV, 362-363).

Doña Perfecta is probably Galdós' best-known villainess. Throughout the novel bearing her name (1876), the reader sees her in perfidious action; but it is only in the climactic moments just before she orders the murder of Pepe Rey that Galdós gives his first detailed physical description. It is important, at this point; for the reader to know that she has "[una] intensa amarillez de su rostro, indicando una fuerte constitución biliosa" (IV, 495). There can be no doubt that Galdós' use of yellow for Doña Perfecta is conscious and deliberate because recent scholarship has demonstrated that he rewrote the ending to this novel. ${ }^{10}$ Among the more mature, more sophisticated changes he made, one finds an additional use of yellow, which echoes the quotation noted above and not only gives Perfecta a kind of ironic repayment for her evil deeds but also leaves the reader with a final and consistently yellow image of her. Instead of allowing Perfecta to remain healthy, happy, and unpunished, Galdós changed his mind and added, "ha perdido el apetito de una manera alarmante... hay un principio de ictericia ... . [y] ella vuelve cada día más amarilla" (Iv, 501). ${ }^{11}$

In the light, idyllic Marianela there is no character low or evil enough to merit yellow, but as Galdós returned to the religious question in $L a$ familia de León Roch (1878), he again used some

${ }^{8}$ See, for example, "Jew Badge," Universal Jewish Encyclopedia (New York, 1948), vI, 89-90 (also picture, I, 351); see also the several references cited by M. Channing Linthicum, "Malvolio's Cross-Gartered Yellow Stockings," $M P$, XXv (1927), 89. Even before Hitler's seizure of power in Germany, Der Große Brockhaus (Leipzig, 1930), vir, 105, listed yellow: "bei den meisten arischen Voelkern ... die Farbe des Neides, Hasses, Geizes, der Streitsucht, Falsch heit, Aechtung."

- Essays, Plays and Sundry Verses, ed. A. R. Waller (Cambridge, Eng., 1906), p. 434.

${ }^{10}$ C. A. Jones, "Galdós' Second Thoughts on 'Doña Perfecta'," MLR, LIV (1959), 570-573.

${ }^{11}$ Cf. Galdós' final disposition of Teresa Amarillo (Iv, 681) 
light touches of yellow. Padre Luis Gonzaga, who, more than any other character, intrudes to destroy León Roch's marital happiness, has "manos largas, amarillas" (IV, 809). León's antipathetic mother-in-law has a citrine cast to her teeth (IV, 783), and Galdós' repeated reference to the green-and-yellow coloring in the eyes of León's wife (IV, 779, 781, 796, 820) reminds the reader of the intense psychic struggle between her sexual passion and her aggressive religious intransigence directed against her liberal-minded husband. ${ }^{12}$

As Galdós turned away from the burning social questions-so prominent in several of his novelas de la primera época (1868-78) - in favor of a more serene and more carefully documented panorama of Madrid life, he had less need for opprobrious yellow. Nevertheless, the following characters are so clearly antipathetic that Galdós does mark them with his stigmatizing color: Gaitica ( $\mathrm{La}$ desheredada), José María Manso and Sainz de Bardal (both in El amigo Manso), and Manuel José Ramón del Pez (La de Bringas) (IV, 1156, 1185, 1193, 1637).

Only with the creation, in 1889, of another major usurer did Galdós return to his former intense use of yellow. Having previously used Francisco Torquemada as a minor character in three novels without any hint of jaundice, Galdós now makes him a yellow-complexioned protagonist. ${ }^{13}$ The author's financial difficulties and his repeated recourse to usurious moneylenders (whom he despised) is well known ${ }^{14}$ and is reflected in the bitterly aggressive tone of Torquemada en la hoguera and seemingly also in the manner in which Galdós repeatedly calls attention to Torquemada's citrine complexion. The usurer has an "amarilla frente" (v, 918), "la perilla amarillenta," and a "color bilioso" ( $\mathrm{v}$, 909); and when he has been through a trying experience, "púsose más amarillo de lo que comúnmente estaba" ( $v, 907)$. In addition, the novel ends in a violent climactic scene with Torquemada swearing and heaping abuse upon an old servant. "Y Torquemada arrojó sobre ella una mirada que resultaba enteramente amarilla, por ser en él de este color lo que en los demás humanos ojos es blanco ...." (v, 936).

In Angel Guerra (1890-91), the very wealthy Dona Sales is described shortly before her death as yellowish. Her coloring is not caused entirely by her illness, for it is soon discovered that she had money, including gold pieces, pathologically hidden in every nook and cranny of the house"una neurosis .... uno de estos recreos cerebrales que la psicología no ha puesto ni quizá pondrá nunca en claro" (v, 1266). Even regarding such minor characters in the same novel as "Tío Anchuras" and "Tía Gencia," one notes the Galdosian comment "Ella no menos seca y amarilla [que él]"; "mujer de . . . sórdidos instintos" $(\mathrm{v}, 1440) .^{15}$

When Galdós returned to the Torquemada series in 1893, he developed a more complex and more carefully drawn protagonist. Galdós himself shows more sympathetic understanding of, and greater identification with, Torquemada. Concurrent with this change of attitude, one notes the complete absence of yellow throughout Torquemada en la cruz. Galdós even forgets the color of his protagonist's goatee $(\mathrm{v}, 961),{ }^{16}$ and only late in Torquemada en el purgatorio (1894) does he return to yellow. Rather than openly expressing his own personal aggressions as he had done in Torquemada en la hoguera ${ }^{17}$ Galdós now illustrates one facet of the old aristocracy's hatred toward the nouveaux riches and their acceptance by many elements of Spanish society. Using the metaphor of the Biblical golden calf, Torquemada's brother-in-law tells the usurer with extreme sarcasm that he should make the main part of his approaching speech center on the fact that he (Torquemada) is the "becerro de oro... de oro puro" and that he should be so worshipped with great pomp and ceremony ( $\mathrm{v}$, 1093).

Finally, in Torquemada y San Pedro (1895), although there is an implied possibility that Torquemada may have been spiritually saved through repentance and conversion, Galdós keeps him physically yellow to the end. Padre Gamborena never knows for sure "qué ideas bullían bajo el amarillo cráneo" (v, 1193).

12 María, perhaps, inherits some of her passionate nature from her father, who is also characterized (but humorously) by green and yellow. When the incurable "viejo verde" (Iv, 783) finds that Le6n Roch will no longer finance his extravagances, "sus sienes, oprimidas y surcadas de venas verdes, tomaban el color amarillento de la cera de velas mortuorias" (Iv, 856).

${ }^{13}$ El doctor Centeno (IV, 1398, 1411), La de Bringas (1v, 1653, 1654, 1665), and Fortunata y Jacinta (v, 194-196). Gald6s also found it necessary to change some other individualizing features, including Torquemada's speech-tag. See my "The Muletilla: An Important Facet of Galdós' Characterization Technique," $H R$, xxIx (1961), 305.

${ }^{14}$ See H. Chonon Berkowitz, Pérez Galdós. Spanish Liberal Crusader (Madison, Wis., 1948), pp. 325, 334-335, 342, 424, et passim.

${ }_{15}$ In the same novel one of the reflections of Padre Francisco. Mancebo's devilish "desmedida afición al sordido ahorro" ( $v, 1333)$ is his insistence on the purchase of (cheaper, foul-smelling) yellow soap for the household $(\mathrm{v}, 1330)$.

${ }^{16}$ Such color inconsistencies are not uncommon in Galdós' creativity; see Shoemaker, p. 212.

17 Note, for example, the aggressive tone in the opening paragraph of the novel $(\mathrm{v}, 906)$. 
In Nazarin (1895), two despicable bandits with "caras famélicas y amarillas" accost and rob the Christlike protagonist and his disciples (v, 1745). The color in this description appears to be an almost involuntary, spontaneous means of stressing the dastardliness of the action; for when Galdós later focuses at considerable length upon the two bandits, he fails to mention either as being yellowish $(\mathrm{v}, 1753-60,1762-66) .{ }^{18}$

In Misericordia (1897), one again notes an instance in which yellow seems to indicate more than mere realistic physical description. Almudena, the blind beggar, who proposes fantastic schemes for acquiring sudden treasures $(\mathrm{v}, 1908-$ $10,1942)$, has a "rostro ... moreno cetrino" (v, 1886), "faz amarilla" (v, 1957), and "frente amarilla lustrosa" ( $v, 1908)$. The latter description significantly occurs as Almudena is expounding the most bizarre of all his wild schemes. ${ }^{19}$ Joaquín Casalduero notes: "La función de Almudena en la novela consiste en descubrir los tesoros que yacen escondidos en la tierra, para que los hombres vuelvan a ser ricos. Pero el sortilegio de Almudena no puede llevarse a cabo, porque él tan sólo promete bienes terrenales. La que hace el milagro de socorrer a los que lo han menester es Benina.",20

However, one observes again that it took something against which Galdós had strong feelings to bring forth a concentrated, heavy use of yellow. Such is true in Casandra (1905), the last of the social novels in which Galdós makes significant use of yellow. Not only Doña Juana Samaniego, the villainess of Casandra, but also four of her important associates are described as sulphur-colored. Doña Juana, who has a "rostro amarillo y rugoso" (vI, 118), is so completely antipathetic that Galdós has his heroine Casandra kill her and then escape almost unpunished. Doña Juana is extremely wealthy and greedy. Her late husband unscrupulously amassed his fortune by taking advantage of Mendizábal's desamortización of Church property, by profiteering during the Carlist Wars, and by squeezing exorbitant interest payments from fellow Spaniards. Rather than invest any of these ill-gotten gains in agricultural or industrial modernization that could benefit progressive members of her family and the Spanish nation as a whole, Doña Juana prefers to buy foreign securities (VI, 120) and finally gives her vast fortune to the Church (vI, 155-156).

Like her jaundiced predecessors-Doña Perfecta, Teresa Amarillo, and Doña Sales-the villainous Doña Juana (who sits upon a "dorado sillón") is associated with the ultra-conservative, intransigent Neo-Catholic point of view. Like these earlier characters (and incidentally Galdós' own mother), Doña Juana seeks to separate young lovers, but Casandra effectively defends her family against this "yellow menace." Juana's stepson, Rogelio, feels she must have had within her body the demons of jealousy and sterility; and there is fear that she may be reincarnated and return to the world after her death in the form of a devil who represents "la envidia; los celos, la avaricia y el egoísmo" (vi, 215)-all symbolic connotative evocations of yellow in the Occident.22

Insúa, Doña Juana's financial administrator, appears with "rostro amarillo y zorruno; ... . un amable Mefistófeles" (VI, 119). Rogelio sees him as "el diablo 'Moloc' conocedor y guardián de los tesoros ocultos" (vI, 131). Insúa's successor, Cebrián, who has a "bigote azafranado," is seen as "Baalberith, canciller del infierno. . . . Toma la figura de un pájaro mojado, con lengua de oro ...." (vI, 136).

The other two yellowish characters are not intrinsically as evil, and they are never said to contain or resemble devils. Don Ventura Nebrija, Doña Juana's parasitic cousin, has a "bigote de moco húmedo, pegajoso y amarillo" (vI, 153). After failing in politics and business, "dando tumbos fué a caer ... bajo la mano piadosa de su prima Doña Juana, que le recompensó . . . la abjuración de sus errores y le metió en cadena de la religión para tenerle bien trincado" (vI, 153). Finally, Doña Cayetana Yagüe, described as a "manga-cruz viviente, negra con galones amarillos" (vI, 174) - the person to whom Doña Juana would forcibly entrust Casandra's children-has no yellow upon her body. She is essentially a good person (VI, 174) with no interest in money (VI, 209). Her only failing is that she is a "beata empedernida" who is too closely associated with Doña Juana and the Church. As she leaves Doña

18 This coloring for the bandits concurs with Gald6s' opinion expressed fourteen years earlier in $\mathrm{La}$ desheredada that for many children, "el raquitismo . . . [les marca] con su sello amarillo ... . inscribiendo la predestinacion del crimen" (IV, 1001). This apparently was not an uncommon opinion. As noted in "Delincuente," Enciclopedia universal ilustrada (Bilbao, Espasa-Calpa, n. d.), XvIr, 1472, the criminologist J. J. Arraez y Carrías found in a study of 150 Andalusian criminals that the only thing significant about their skin was that some had "cierto tinte amarillo verde."

${ }^{19} \mathrm{~V}, 1908-10$. Cf. the choice of descriptive words and functional technique concerning Teresa Amarillo, created seventeen years earlier (rv, 598, 652).

${ }^{20}$ Vida y obra de Galdós (Madrid, 1951), p. 252.

${ }^{21}$ Doña Juana is "slant-eyed" (vi, 118).

${ }^{22}$ See "Jaundice," The Oxford English Dictionary (Oxford, 1933), v, 558; see also "yellow" both in O. E. D., XII, 34-36, and in Gertrude Jobes, Dictionary of Mythology, Folklore and Symbols (New York, 1961), I, 1704. 
Juana's palace, one notes that "lo que amarillea es un lío que trae envuelto en pañuelo negro con franjas de azáfrán. El lío parece ... . [tener] ropas de altar" (vI, 174).

The examples here given clearly demonstrate that Galdós used yellow as a conscious, effective facet of his characterization technique throughout the major part of his long literary career. The citations show a complete lack of interest in the Golden Age stereotyped symbolism of desesperacio $n^{23}$ and reflect, instead, the common Occidental notion of yellow as a symbol of opprobrium.

Yellow is not only sometimes considered a discoloration of white (or purity), ${ }^{24}$ but (as noted above) it is also a symptom of any disease which damages normal liver function and is reflected in such names as yellow plague, yellow fever, and (yellow) jaundice. Because of the universal fear of contagion and the former close association of illness with evil and the devil, it is understandable that yellow should have become in the Occident the color not only of quarantine and social outcasts (Jews, orphans, convicts, heretics, prostitutes, etc.) but of evil doers and the devil as well. ${ }^{25}$. From these values the more extended nuances of usury, avariciousness, quarrelsomeness, treachery, and cowardliness probably evolved. ${ }^{26}$ In any case, it is within this wide range of connotative values that Galdós describes and delineates his sulphur-colored characters. Yellow, whenever symbolic values are implied, is for Galdós a consistently negative, opprobrious color. One never finds such admirable Galdosian heroes as Pepe Rey, Daniel Morton, León Roch, Máximo Manso, "Nàzarín," Benina de Casia, Casandra, and others delineated with yellow. Only after he has j"el hígado partido por la profunda cuchillada" of assassins - one of whom is significantly named Fausto-can Galdós describe a personaje like Angel Guerra as being yellowish (v, 1532).

Even some of Galdós' uses of yellow for inanimate objects demonstrate that the color had emotionally charged, unpleasant values for him. Pepe Rey in Doña Perfecta, for example, drifts into the gambling room of Orbajosa's casino. Galdós says only, "Cerca de dos horas estuvo en las garras de aquel demonio amarillo, cuyos resplandecientes ojos de oro producen tormento y fascinación" (Iv, 442). In La familia de León Roch, Galdós notes a yellow-colored landscape and comments, "infunde cierto pavor dantesco en el corazón" (Iv, 813). Some characters also register fear at the sight of yellow. ${ }^{27}$ And finally, in Lo prohibido, Raimundo Bueno de Guzmán has made a "Mapa moral grafico de España" on which he notes as part of his explanatory key: "Inmoralidad pecunaria, usura, disipación, color amarillo" (Iv, 1800).

Because of the long history of stigmatizing connotations for yellow in the Occident, it is not surprising that Galdós should choose to use it for the same values. One does not have to look far to find probable direct literary sources that influenced Galdós. In his own library, the works of Balzac and Dante were prominent. ${ }^{28}$ The $I n$ ferno, for example, reveals that as early as the Middle Ages, yellow was used connotatively in literature. As noted above, Galdós associated "amarillo" with "pavor dantesco." His reason for doing so may well be derived from the fact that the terror-inspiring climactic scene of the Inferno presents the devil himself (in a blasphemy against the Trinity) with three faces-one of

23 For details concerning the full range of color values in Spanish Renaissance literature, see: Herbert A. Kenyon, "Color Symbolism in Early Spanish Ballads," $R R$, vi (1915), 327-340; S. Griswold Morley, "Color Symbolism in Tirso de Molina," $R R$, vIII (1917), 77-81; W. L. Fichter, "Color Symbolism in Lope de Vega," $R R$, xvirr (1927), 220-231.

${ }^{24}$ For example, see Cowley, p. 434. Whiteness in Galdosian characterization frequently symbolizes purity; see, for example, my "Galdos' Sephardic Types," Sym, xvir, 94. Galdós uses yellow not only as a sign of discoloration (frequently using the simile of old paper) in physical descriptions but also for inanimate objects as well. The documents in the hated Inquisition office (El audaz, IV, 393), for example, are an unpleasant yellow, as is the crucifix on the wall.

${ }^{25}$ See "Quarantine," The Encyclopaedia Britannica (Cambridge, England, 1911), xIr, 710. For social pariahs in general, see Linthicum, "Malvolio's ... Yellow Stockings," $M P$, Xxv (1927), 89. Also, for Jews, see n. 8 above. For convicts, Jobes, Dictionary, II, 1704; Geo. Kennan, Siberia and the Exile System (Chicago, 1958), p. 30; Stephen Crane, Maggie and Other Stories (New York, 1960), p. 2; and n. 18 above. For heretics, see n. 33 below. For prostitutes, see Fyodor Dostoyevsky, Crime and Punishment, trans. Constance Garnett (New York, 1958), pp. 336, 341. Another reason for the popular belief that yellow is the devil's color probably derives from the fact that the devil is thought to smell of sulphur, which is, of course, yellow in color. Lake Avernus, near Naples, "because of its mephitic and sulphurous vapors was thought by the Greeks and the Romans to be the entrance to the infernal regions. Through it Odysseus and later Aeneas were said to have entered the lower world" (Jobes, $\mathrm{II}, 965)$. Hence the perennial notion that hell-fire is sulphurous. See also n. 29 below.

${ }^{26}$ See nn. 8, 18, 22, and 25 above.

${ }^{27}$ Rafaelito Carrillo (Lo prohibido), IV, 1755; Fortunata, and Luisito Cadalso (Miau), both in v, 265, 635.

${ }^{28}$ Gald6s' library contained Balzac's EEuvres complètes, 46 vols. (Paris, 1856-77) and four different editions of Dante's Divine Comedy. H. Chonon Berkowitz, La biblioteca de Benito Pérez Galdós (Las Palmas, 1951), pp. 178, 193. 
which is yellow. ${ }^{29}$ Dante also seems to indicate an association of yellow with avariciousness by depicting the first of his money-lenders in hell still clutching the yellow (gold-filled) purse which caused his perdition (Canto xvii). Balzac, whose Comédie humaine first inspired Galdós to become a novelist, ${ }^{30}$ significantly fuses these disparate elements in Dante and combines the qualities of devilishness, yellow, and greed in his presentation of the pawnbroker Samanon in Illusions perdues. "Est-ce le diable?" queries one character concerning the shrewd and avaricious moneylender who, like many of Galdós' characters, has yellow hands and a yellow forehead. ${ }^{31}$ In addition, Gobseck and Grandet, Balzac's wellknown misers, have yellow eyes-as does Galdós' Torquemada, ${ }^{32}$ and characters in El doctor Centeno repeatedly refer to Torquemada as Gobseck (IV, 1364, 1372, 1411).

Thus it can be seen that the creative originality of Galdós lies not in his choice of color but must rather be sought in the adaptation of it to his own particular value system and style of writing. He especially delighted in reversing the traditional usage of the color of opprobrium. As noted in the case of Juan Amarillo in Gloria, the Christian and not the Jew is the villainous usurer and is plainly marked with a yellow complexion and surname for all to observe. Also Torquemada, bearing the same name as Spain's most infamous Grand Inquisitor, likewise assigns no penances of yellow sambenitos, yellow crosses to be sown on garments, or yellow candles to be carried in a procession ${ }^{33}$ but is himself already so thoroughly stamped with the repugnant color that even the whites of his eyes have long since turned yellow. Those fanatical religious intransigents, Doña Perfecta, Doña Salomé, Teresa Amarillo, Doña Sales of Angel Guerra, and Doña Juana Samaniego of Casandra-all of whom would be the first to call anyone differing with their religious views a heretic-are themselves plainly marked with the heretic's color. Likewise in Casandra, those who scheme for the temporal and financial aggrandizement of the Church are not only stigmatized with yellow-as is Judas traditionally in Christian art ${ }^{34}-$ but are openly and repeatedly designated by Galdós as incarnations of the devil.

Even such a seemingly small detail, then, as the coloring of a character's eyes and complexion may reveal the feelings of Galdós toward his personaje and the transcendental values he represents. Of all the human frailties and failings that Galdós observed and recorded throughout his long career, there seem to be really only two that he could not forgive: fanatical religious intransigence that tends to destroy love, and lust for wealth, which in its worst form is usury. ${ }^{35}$. For Galdós, personajes afflicted by these sins needed to be stigmatized clearly with the opprobrious color of illness, the social outcast, and the devil.

\section{UNIVERSITY OF KANSAS Lawrence}

${ }^{29}$ Dante Alighieri, "Inferno," Le opere di Dante (Firenzi, 1921), p. 597. This chromatic symbolism has been variously interpreted as impotence, envy, and avarice, as may be seen in the translator's notes: The Divine Comedy, trans. John D. Sinclair (London, 1939), p. 430; and in the version by Henry Francis Cary (A. L. Burt Co., n.p., n.d.) p. 156. For additional references to yellow as the devil's color, see n. 25 above; Archer Taylor and Bartlett J. Whiting, A Dictionary of American Proverbs and Proverbial Phrases (Cambridge, Mass,, 1958), p. 416; and James G. Frazer, The Golden Bough (New York, 1949), p. 696.

30 "Memorias de un desmemoriado," Obras completas, vi, 1656, 1693.

31 Paris, Calmann-Lévy, n.d., I, 214-216.

32 "Gobseck," CEuvres complètes (Paris, 1875), III, p. 466; and Eugénie Grandet (Paris, Calmann-Lévy, n.d.), p. 8. Because Grandet is such an inhuman miser (more so than Torquemada), Balzac even calls attention to the dingy yellow walls in part of his house and his use of cheap, shopworn yellow candles (p. 61). For an especially ruthless and jaundiced villain of Balzac's, note M. Troubert in Le Curé de Tours; his accomplice, Mlle. Gamard, significantly lives in a "salon jaune." Euvres (Paris, 1913), Ix, pp. 208, 204.

An examination of all the references to yellow in Dickens' novels as listed in the $O$. E. D., XII, 34-36, does not reveal any sharing of Balzac's and Galdos' values for yellow. Two American authors, however, who do use yellow with unpleasant, stigmatizing connotations are Stephen Crane, Maggie, pp. 6, 7, 16, 60, 175, and Thomas Hal Phillips, The Golden Lie (New York, 1951), pp: 4, 5, 44, 46-47. Ivan Schulman, Símbolo y color en la obra de José Marti (Madrid, $1960)$, p. 458 , finds that yellow in the works of the Cuban patriot "señala decadencia, muerte, melancolía o impureza moral."

${ }^{33}$ For sambenito, see O. E. D., Ix, 80; for crosses of infamy, see G. C. Coulton, Inquisition and Liberty (London, 1938); p. 127 (also picture, p. 136); for candles, see "Auto da fé,", Universal Jewish Encyclopedia, I, 640. With the increasing use of yellow by the Inquisition, there occurred, it seems, a parallel decline in its popularity as an acceptable liturgical color after the fifteenth century. Finally it was proscribed. Cf. "Colours," The Catholic Encyclopedia (New York, 1908), IV, 135.

${ }^{34}$ George Ferguson, Signs and Symbols in Christian Art (New York, 1954), p. 275.

${ }^{35}$ Cf. Berkowitz, Pérez Galdós, on religion, pp. 72-73, 139-141, et passim; on usury, n. 14 above. 